\title{
EL TOTEMISMO ENTRE LOS ANTIGUOS PERUANOS
}

\author{
José Antonio Encinas
}

(Ex-Rector de la Universidad Nacional Mayor de San Marcos)

Propósito.

La presente contribución que ofrezco sobre el Totemismo entre los antiguos peruanos no se propone elaborar una nueva teoría totémica. Su finalidad es más modesta; se reduce a estudiar en la Historia prehispánica del Perú los elementos totémicos más importantes, aquellos, generalmente, admitidos como tales, y deducir de su análisis la existencia o no del Totemismo entre los antiguos peruanos.

Concepto de Totemismo.

"Jorge Puccinelli Converso"

He encontrado gran dificultad en orientar esta investigación en medio de la confusión que envuelve el problema del Totemismo para cuya explicación el Profesor Van Gennepp ofrece en su libro 'L'Etat Actuel du Problem| Totemique", cuarenta y nueve teorías. ¿Cuál de ellas debía preferir, por lo menos, como punto de partida para abordar el estudio del totemismo en el Perú? He allí una cuestión difícil para decidirse. Muchas de esas teorías no son utilizables para interpretar los hechos que, en el Perú, parecen poseer caracteres totémicos. No me pareció apropiado emplear el método comparativo en donde es posible encontrar analogías fáciles de acomodar a cualquiera de las doctrinas enumeradas por el citado Profesor.

De la variedad de esas teorías he adoptado la más sencilla, la que mejor explica los hechos atribuídos, como totémicos, en la Historia peruana.

Esa teoría es la siguiente:

El totemismo considera:

19- La existencia de una organización social cuyos miembros suponen encontrarse en relación de parentesco. 
2:- La presencia de animales, plantas u objetos inanimados de los cuales creen descender los miembros de esa organización social.

Elementos totémicos en el Perú.

El estudio de la literatura existente sobre el Totemismo, y la revisión cuidadosa de los cronistas españoles y de cuantos han estudiado la Religión en el Perú, ofrecen los siguientes elementos totémicos:

19- La organización llamada Ayllu cuyos miembros se consideraban unidos por razón de parentesco.

2? La presencia de animales considerados como ancestrales.

39- La presencia de la Huaca, objeto inanimado, (cerro, loma, río), que daba nombre al Ayllu y a sus miembros quienes creían descender de la Huaca.

Fuentes históricas y opiniones acerca del Totemismo en el Perú.

El Totemismo entre los antiguos peruanos no ha merecido, hasta hoy, particular estudio. Los sociólogos, etnógrafos, arqueólogos, retiriéndose a la Religión en el Perú, lo han hecho, superficialmente, cuando han tratado de interpretar algunos elementos religiosos como de naturaleza totémica. Ellosi se han fundado en los datos aportados por los cronistas españoles quienes al referirse a la vida religiosa de los indios ofrecen hechos, de este orden, bastante impregnados con las creencias cristianas al extremo de ser difícil la correspondiente discriminación. Arriaga, Avila, Molina son los que mejores informes proporcionan sobre asuntos religiosos. Cieza de León, Garcilaso, el Jesuita Anónimo, Montesinos, Pachacutec, 'Ondegardo, Betanzos y Cobo, lo hacen en menor grado.

Estos cronistas ofrecen lo siguiente:

1.- Algunas leyendas de los antiguos peruanos en donde oparecen animales, plantas y objetos inanimados en relación directa 0 indirecta con el grupo social dominante.

2:- La descripción de creencias, ceremonias, sacrificios, danzas y prácticas mágicas referidos a los animales.

30- La descripción de la Huaca, Pacarina, Conopa y Malqui, elementos peculiares de la vida religiosa peruana.

40- La descripción de la vida económica, política y religiosa del Ayllu. 
La interpretación de los hechos ofrecidos por los cronistas corresponde a quienes se han ocupado del fenómeno religioso pre-hispánico. De esos escritores obtenemos las siguientes opiniones relativas al Totemismo.

LANG, refiriéndose al Perú pre-hispánico dice: "que lả Religión en aquél período fué meramente mágica y totémica."

M'LENNAN, manifiesta que en el período de la dominación de los incas "reinó el naturalismo sobre una previa etapa totémica".

PAYNE, ocupándose de la idolatría pre-incaica sostiene que este sistema, la idolatría, fué "el sistema peculiar tan extendido entre los pueblos salvajes, que es a veces conocido como totemismo".

FRAZER, dice que "los datos que se tienen de la religión y las supersticiones de los aborígenes del Perú hacen suponer que quizá ese pueblo tuvo totemismo o algo semejante. Pero las pruebas que se ofrecen son tan débiles que no permiten emitir una opinión definitiva sobre la materia".

HARTLAND, ocupándose del totemismo entre los pueblos no-totémicos dice: "Se han interpretado algunas costumbres y creencias de de la América Central y la del Sur como residuos de totemismo. Assí, en el Perú, donde fueron localizados varios clanes, cada uno adoraba a sus antepasados, manifestándose esta tendencia hacia objetos que tenían la forma de unanimal o de un vegetal".

LEWIS SPENCE, intentando demostrar eP naturalismo religioso de los antiguos peruanos dice: "es difícil deducir una religión totémica fundándose en la adoración prestada por los antiguos peruanos a la Naturaleza y a los animales. Si en la Religión del Perú hubiera existido el totemismo, habría dejado profundas huellas como sucedió entre los egipcios. En este caso algunas de sus deidades más importantes acusarían origen totémico. Lo cierto es que estas deidades revelan un fondo totalmente naturalista ... Los ingredientes de la religión azteca eran casi totalmente totémicos, mientras que los de la religión peruana eran naturalistas".

Refiriéndose a Garcilaso afirma: "que la evidencia aportada por Garcilaso parece indicar que los primitivos peruanos poseían un sistema totémico que parece, sin embargo, haber sido totalmente
eliminado por algún proceso aun desconocido".

LATCHAM, sostiene que "como regla general, el totem no es ni puede ser confundido con el ancestral, y por lo tanto muy pocas tribus creían descender de un totem .... El totem era el ser tutelar pesonajes son bien conocidos y distinguidonza o pacto y ambos 
bros del grupo". En consecuencia, "ni los Incas, ni los Collas, ni los Araucanos pensaron nunca descender de un totem".

Sin embargo, apesar de esas afirmaciones que destruyen toda idea de totemismo entre los primitivos peruanos, Latchman acepta la existencia del totemismo entre los indios andinos, pero concibiéndolo como fraternidad, o más bien como deidad tutelar. Por eso, después de estudiar los elementos totémicos dice que "Sarmiento, Acosta y Ondegardo hablan del totem y lo designan con su verdadero nombre de Huauqui, pero no comprenden en lo absoluto su significación". Apoyándose en Arriaga expresa que "cuando una mujer está preñada, frecuentemente llama al shaman para hacer un sacrificio a su conopa (totem) personal".

Finalmente al referirse a los nombres que se daban en las ceremonias de iniciación dice "tales nombres eran los de la familia Huaca o totem, que como hemos visto pertenecen a la familia o clan".

Otros escritores han interpretado el Totemismo peruano siguiendo las orientaciones de determinadas teorías sociológicas. Pérez Palma, aplicó al totemismo, la teoría de la encarnación. P. Aguila mantiene que el-totemismo "es un culto y el totem un Dios". Finalmente, tomando como base las investigaciones arqueológicas de las dos últimas décadas, Tello sostiene que la religión de los primitivos peruanos se apoya en bases totémicas.

Por lo general las autoridades enunciadas han emitido esas opiniones, juzgando al totemismo como una etapa del proceso de la religión. Otros, han tomado, como fuente del totemismo peruano, las narraciones de los cronistăs cuăndo en ella's hāy referencia a cualquier animaì como sujeto de adoración, sacrificio, ceremonias mágicas y danzas.

Jtros escritores como Bandelier, iSquier, Cunow, Tshudi, Prescott, Markham, Príncipe, Uhle, Poniasky, Joyce, Trimborn, Baudin, Means, Karsten, Paredes, Jijón y Caamaño, Valcárcel, ofrecen valioso aporte al totemismo peruano cuando interpretan los elementos totémicos encontrados en la antigua Historia del Perú. A ellos, me refiero, con frecuencia, en el curso de mi investigación.

Fuera de las mencionadas fuentes, nada es posible encontrar en la vida actual de los indios frara averiguar si participaron o no de una organización totémica. Los aborígenes peruanos no se encuentran en las mismas condiciones de las tribus de Australia. En su mayoría viven mezclados, en la existencia cotidiana, con los blancos y los mestizos.

Pocas son las creencias religiosas antiguas que ostensiblemente sobreviven en el indio. En los indios de la sierra del Sur del Perú hay mayor consistencia en la idea de antepasado, llamado achachila, nombre generalmente, atribuído a los cerros que, todavía, reciben homenajes consistentes en ceremonias mágicas. Pero, por ejemplo, la original concepción de Huaca ha desaparecidc. En esto situación, el indio, en materia religiosa vive en un laberinto de supersticiones. Con todo, una minuciosa observación de su actitud mental nos muestra la existencia, 
en su espíritu, de una fuerte inclinación hacia el naturalismo, siendo el Catolicismo un mero disfraz para ocultar el verdadero contenido religioso.

La dificultad para una minuciosa investigación sobre el totemismo peruano crece si se tiene en cuenta que la antigua civilización peruana se desenvolvió sobre un inmenso territorio en donde los elementos físicos y climatológicos ejercieron manifiesta influencia.

Aunque en algunas regiones del Perú, especialmente en la sierra del sur, sobrevive el Ayllu conservando su organización económica y aun social, es difícil investigar el contenido religioso primitivo, pues nada ha quedado de la relación entre el Ayllu y la Huaca, nada sobre el sistema de parentesco que unió a sus miembros, menos la antigua creencia de haber descendido de los animales. En consecuencia, una investigación "sobre el terreno" resulta imposible.

Teniendo en cuenta estas dificultades, resulta difícil asegurar completo éxito en una investigación de esta especie. Sólo es dable apoyarse en los hechos históricos ofrecidos por los cronistas, en la interpretación verificada por los sociólogos, etnógrafos y arqueólogos que se han ocupado de buscar elementos totémicos en la primitiva historia del Perú.

Plan del estudio totémico en el antiguo Perú.

De acuerdo con los elementos totémicos ya enunciados, la investigación acerca del totemismo en el antiguo Perú debe comprender las siguientes cuestiones:

1.- El estudio de las leyendas peruanas, para averiguar si ellas tienen algún contenido tolémico.

2.- Si los animales fueron considerados como dioses, protectores, símbolos o tótemes.

3.- Si la Huaca fué elemento totémico del Ayllu.

4.- Si el Ayllu fué una organización social totémica.

\section{LAS LEYENDAS}

Es evidente que todas las tribus peruanas, llamadas "Naciones" por los Españoles, tales como los quechuas, chancas, collas, pocras, etc., tuvieron sus leyendas. Desgraciadamente, muy pocas fueron recogidas por los cronistas. Hemos averiguado si entre los indios peruanos actuales existen vestigios de sus antiguas leyendas. El intento ha fracasado; los indios del Perú han olvidado las maravillosas leyendas de sus antepasados.

Para el presente estudio es necesario analizar las leyendas trascritas por los cronistas con el propósito de buscar en ellas las pruebas fehacientes de la existencia, o no, de una organización totémica. Para este efecto la leyenda debe referirse a una organización social en donde los miembros integrantes se encuentren en relación de parentesco 
con el animal, la planta o el objeto inanimado que aparezca como protagonista de la leyenda.

Las leyendas peruanas deben clasificarse de acuerdo con el asunto de que tratan $\mathrm{y}$, luego, en relación con la región geográfica en donde se han desarrollado. Debemos, además, considerar separadamente las leyendas generales y las locales. Las primeras son aquellas que parecen haberse extendido sobre largas porciones del territorio peruano como sucede con las de Viracocha y Pachacamac. Las segundas pertenecen, exclusivamente, $a$ una tribu o a un grupo reducido de tribus como la de los cañaris.

Desde un punto de vista geográfico, las leyendas de la Sierra tienen radio más amplio de influencia que las de la Costa a causa de la mayor expansión de la cultura serrana.

La preponderancia del imperio del Tahuantinsuyo determinó una aglutinación de las leyendas originarias con las que se refieren al sol. A pesar de este hecho, las leyendas primitivas tanto de la costa como de la sierra mantuvieron su integridad.

Las leyendas generales más famosas son las llamadas de Viracocha y Pachacamac. Ambas tienen por tema central la creación del mundo y la de los primeros habitantes. La de Viracocha corresponde a la Sierra; la de Pachacamac a la Costa. Aun cuando ellas tuvieron su origen en puntos determinados de la costa y de la sierra, constituyen, sin embargo, la creencia general de lós habitantes de estas grandes extensiones territoriales.

La leyenda de Viracocha es la más completa en los aspectos cosmogónicos y antropogónicos. Es el mito que de manera más comprensiva explica la evolución social y económica de la Sierra. En esta leyenda no hay vestigio alguno de la intervención de animales en la vida individual o colectiva de los aborígenes. Viracocha creó a los hombres, no como individuos sino como grupo social procedentes de cuevas, ríos y montañas, por eso tiene el valor específico de haber grabado en la mente del indio la idea de proceder de esos elementos geográficos.

La leyenda de Pachacamac, debido al intercurso de las civilizaciones existentes en cada valle de la costa recibió la influencia de variaclas actitudes mentales. En la primera parte, el Sol aparece como padre de Pachacamac cuando, en verdad, es el protector del agregado social, mostrúndose, a veces, con poderes superiores a los del Sol. Hay una rivalidad permanente entre Pachacamac y el Sol; una relación sexual entre el Sol y su nieta; la reintegración de las partes del cuerpo del hijo del Sol a quien había dado muerte Pachacamac; y la presencia de tres huevos (oro, plata y cobre) de los cuales descienden respectivamente, los gobernantes, los nobles y el pueblo.

En estar leyenda. la mágia interviene en gran proporción. Por medio de ella, Pachacamac sacó de las diferentes partes del cuerpo de su hermano todas las plantas alimenticias existentes.

En mi opinión esta leyenda interpreta el problema económico. La rivalidad entre el Sol y Pachacamac tiene su origen en la escasez de alimentos. Pachacamac pone en acción toda su potencia mágica para obtenerlos. En ninguna parte hay vestigios de elementos totémicos. No 
aparecen animales ligados al grupo social. Sólo en la última parte encontramos el origen ovíparo de las clases sociales.

Entre las leyendas locales hay algunas que aparecen acusar caracteres totémicos.

En la leyenda de los cañaris aparecen dos aves llamadas Huacamayos vestidos como los cañaris las cuales dieron de comer a dos hermanos salvados del diluvio. Después de muchos incidentes, el menor de los hermanos tuvo relación sexual con el ave de cuyos hijos, que fueron seis, creen descender los cañaris. Tienen por huaca al cerro llamado Huacayman y en gran veneración a los Huacamayos cuyas plumas les servían para sus fiestas. Desgraciadamente no poseemos referencia alguna sobre la organización social de los cañaris, de la cual podíamos deducir la verdadera posición del Huacamayo en su complejo cultural.

La leyenda de Coniraya o Kon-Iraya no parece arrancar de fuentes totémicas, aunque es interesante observar que Coniraya, el Creador, trasformado en un hermoso pájaro trepó el árbol llamado lúcuma del cual tomó algunas semillas. Una vez madura la lúcuma cayó cerca de la virgen Cawillaca que tejía un manto al pie del árbol. Cawillaca comió la fruta dando, poco después a luz un hijo. Sin embargo Cawillaca no parece regir el grupo social. En cambio Coniraya subordina a su voluntad a los animales. En todo caso la leyenda de Coniraya muestra un conflicto económico sobre la multiplicación de los peces.

En la leyenda de Pariaccaca encontramos ciertos caracteres aparentemente relacionados con una organización totémica primitiva, pero un análisis cuidadoso de sus elementos nos muestra que los animales desempeñaban el papel de protectores. El héroe Patriarca fué al Ayllu Copara donde no había agua. Allí limpió las montañas e irrigó las tierras. En este trabajo, el héroe lué ayudado por los animales que vivían en la región. Por consiguiente esta leyenda tiene carácter económico.

En la leyenda de Apokatekil ocurre el mismo conflicto económico entre dos grupos Huachemines y Huamasiris. Al principio los Huamasiris eran los trabajadores. Después del conflicto cuando los Huachemines fueron derrotados, entonces, éstos, suplicaron a Ataguju, el Hacedor, crease hombres para arar la tierra.

Como vemos, en estas leyendas, el factor económico es el preponderante. Los animales aparecen como elementos secundarios interviniendo, mágicamente, en mejorar la tierra, en cultivarla y en proporcionar el mayor número de alimentos en beneficio de la colectividad.

Resumen.

En resumen podemos decir lo siguiente:

1.- Que las leyendas peruanas se originaron en grupos sociales diferentes.

2.- Cuando esos grupos se confederaron, entonces las leyendas se superponen siguiendo un método estratigráfico, como ocurre con las leyendas de Pachacamac y Viracocha. 
3.- Las leyendas generales son de carácter cosmogónico o antropogónico, rara vez teogónico.

4.- En las leyendas locales hay referencia a los animales considerados como sujetos que cooperan al bienestar económico de la colectividad sin regular la organización social ni establecer relación de parentesco.

5. - Por tanto no hay fundamento alguno para atribuir contenido totémico a ninguna de las leyendas generales o locales, trasmitidas por los cronistas.

\section{LOS ANIMALES}

En la organización social totémica, el animal constituye el más importante de los elementos. Sin embargo estudios posteriores sobre la materia han puesto en evidencia que el animal no siempre desempeña un papel totémico en la organización social. El animal puede ser considerado como: a) Dios.- b) Protector.- c) Ancestral.- d) Símbo10.- e) Totem. Veamos a cuál de estas clases pertenecen los animales que tanto influyeron en la vida de los antiguos peruanos

En las leyendas examinadas, los animales no aparecen como deidades o dioses, sino como subordinados a potencias superiores.

En ningún caso actúan como creadores o dominadores del grupo social. Ninguno de ellos puede ser considerado como sagrado ni como sujeto de adoración, porque ni pueden actuar independientemente, ni los miembros del grupo se sienten sometidos a ellos.

En las leyendas aparecen, los animales, como creados por un Ser Supremo quien"les otorgó poderes y dofes, regulando, al mismo tiempo, las ceremonias, sacrificios y danzas que debían celebrarse en su honor.

Así como las leyendas tienen claro sentido económico, los animales que en ellas aparecen tienen carácter de Protectores. Constituyen la fuente de los alimentos, ayudan a construir la casa, a mejorar la tierra, a limpiar los montes. Sirven como intermediarios entre el Dios del Cielo y los distintos héroes de las leyendas. Son los que salvan de toda desaracia, a los miembros del agregado social.

Son numerosas las referencias proporcionadas por los cronistas acerca del papel que desempeñaron los animales en la vida social y religiosa de los nrimitivos peruanos.

Los animales como deidades y sujetos de adoración.

Los cronistas suministran información que deja en total oscuridad muchas cuestiones indispensables para la correcta interpretación de sus relatos. Según ellos; los indios adoraban todo; animales o cerros, aunque la actitud aborigen hacia la Naturaleza no era exactdmente de "adoración". Los términos adorar y adoración se usan con gran abundancia pero con poca discriminación al examinar los hechos relaciona- 
dos con los animales. Del mismo modo, cuando los cronistas notifican que el indio creía descender de animales, no especifican cuál era la clase de parentesco que implicaba esta curiosa creencia.

Para la mentalidad primitiva peruana, los animales habían sido creados por el Ser Supremo, a quien "miraban con gran miramiento y gratitud, pues le debían todo lo que eran y todo lo que tenían".

En el Perú, según Acosta, antes de la conquista ya existían toda clase de animales, "bestias salvajes y leones, tigres muy crueles, muchos osos y zorras, perros y pájaros, huanacus y vicuñas".

Prácticamente todos esos animales eran objeto de adoración, actitud que prevaleció en el período del Incanato y aun en el del Virreinato.

De esos animales, unos eran adorados por su fiereza o monstruosidad; otros por los beneficios materiales que rendían; no pocos por su belleza y dotes particulares.

Había provincias en donde los indios adoraban cierta clase de animales, aunque consideraran como Dios a un animal especial.

En ciertos casos, los indios representaban a esos animales mediante esculturas en barro, guardándolos como ídolos, en las casas y templos.

Los animales como ancestrales.

Veamos, ahora, las referencias de los cronistas en relación con el ancestro animal. Recordemos, en primer término, las informaciones de Garcilaso que han servido para suponer la existencia del totemismo en el Perú. Garcilaso dice: "que no se tiene por honrado un indio que no desciende de fuente, río o lago, aunque sea de la mar, o de animales fieros, como el oso, león o tigre, o del águila, o del ave que llaman cundur, o de otras aves de rapiña, o de sierras, montes, riscos o cavernas, cada uno como se le antoja, para su mayor loa y blasón".

Específicamente, los Chancas alardeaban descender de un león, y en consecuencia lo adoraban como a un Dios. Los Cañüris creían descender del pájaro Guacamayo. Los Antis, aunque no creían descender la tierra. Del mismo modo los Collas, rendían culto a las liamas porque ellos que no de los demás indios".

Todos estos y otros datos ofrecidos por los cronistas no se refieren particularmente a un determinado Ayllu en doncie un animal representara y ejerciera la misión totémica correspondiente. Es difícil sostecasos y aislados datos aportados por los el Perú fundándose en Ios esción y ancestro ligadas con elementos zoológistas. Las ideas de adorara atribuir a los peruanos, aun en tiempos mos no son suficientes patotémico. 
Sacrificios.

Los antiguos peruanos, además de considerar a los animales como ancestraies o deidades, practicaban con ellos variadas ceremonias mágicas, usándolos para sus sacrificios.

Había dos clases de sacrificios: a) el KOKU en el cual se ofrecían solamente frutas, raíces etc., desarrollando el ceremonial cerca de los ríos, lagos, rocas y otros lugares donde los indios creían reconocer la presencia de seres invisibles; b) el ARPHA que consistía, por lo general, en tomar ciertos animales y despojarlos de sus entrañas.

Los sacrificios se verificaban como homenaje a las deidades entre las cuales no estaban incluídos los animales. La emoción religiosa del indio surge de la impresión provocada por las fuerzas de la Naturaleza y no por la presencia de los animales. En la sierra es el Trueno, el Relámpago, las montañas gigantes. En la Costa es el mar. De allí los sacrificios en homenaje a Viracocha y a Pachacamac, símbolos de la Naturaleza. Desaparecido el símbolo sacrificaban en honor al Trueno, al Relámpago, al Sol, a la Luna, a las estrellas.

Prácticamente, todos los animales a los que se les ha supuesto rasgos totémicos, aparecen como subordinados a las estrellas. Las culebras y serpientes a Machachuay. Los tigres, los leones y los osos a Chunchincay. La llama y sus especies afines a Urcuchillay.

Dos clases de sacerdotes tomaban parte en las ceremonias de sacrificio. El Riruk que extraía las vísceras de las víctimas y el Villac que se comunicaba con las deidades a quienes se dedicaba el sacrificio. El primero aparece en todas partes y está conectado con diferentes animales, recibiendo las denominaciones de Amaru Riruk, Cuyi Riruk. El segundo está en relación con las deidades $y$, así, era llamado Punchao Villac, Illpa Villac.ge Puccinelli Converso"

Cume se ve no hay sacerdotes dedicados al culto de los animales. Los Villac hablan con el Sol, el Trueno y las Huacas. Los Riruk consideraban a los animales como instrumentos para las ceremonias mágicas, mas no como deidades o agentes de alguna organización social. Esas ceremonias eran prácticas mágicas para lograr el mayor beneficio económico de la colectividad. En ellas no hay similitud con las ceremonias totémicas, las cuales tienen como propósito la multiplicación del totem. El Tabú.

El tabú se relaciona íntimamente con el sacrificio. En su sentido general, esta paiabra expresa la prohibición del uso o consumo de ciertos obietos considerados como sagrados. Los peruanos llevaron esta creencia a grados muy elevados. Los quechuas tenían la palabra Sasi que, literalmente, significa ayuno, pero tomada en sentido amplio implica la idea de abstenerse de realizar algo, sea una actividad física (comer, dormir, trabajar etc.) o una espiritual, como la de divertirse. Colocando esta palabra, con el sufijo cuni, delante de un sustantivo, expresa la idea de un tabú específico: sasicuni huarmimanta, sasicuni micuymanta (me abstengo de la mujer; me abstengo de comer). 
El Sasi se practicaba en ocasión de ciertos festivales y con propósitos mágicos. En la fiesta llamada Situa estaba prohibido el consumo de toda clase de carne, pescado o vegetales. Había otros sasis menores. Pero no parece haber habido ningún tabú relacionado con animales considerados como tótemes. Los Jaujas consideraban al perro como animal sagrado. De este hecho se ha atribuído al perro como totem de esa tribu. Pero los Jaujas comían la carne del perro. Ocurría lo mismo con la llama, supuesto totem de los collas.

Si a los peruanos les estaba permitido comer la carne de los animales sagrados, considerados como tótemes, no podemos admitir la existencia del totemismo en el Perú antiguo.

Las danzas.

También se ha pretendido encontrar en las danzas, pruebas de una organización totémica. En las danzas que sobreviven abundan muchas en las cuales se representan las costumbres de los animales, imitando sus actitudes, utilizando las pieles como disfraces y adornándose con plumas, dientes y cuernos.

La variedad de las danzas era enorme. Había palabras especiales para designarlas. Los vocablos generales eran: Tusuy, en quechua, y Chilchi Taqui, en aimara. La danza ceremonial recibe el nombre de Yahuayra. La danza guerrera Aucca Tusuy. La danza de los enmascarados, Aranya. De acuerdo con ciertos movimientos, llamaban Cashua a la danza en círculo y Huayñuni Cashua a la danza en que los participantes se daban la mano.

Cuando Molina describe las fiestas celebradas cada mes, en el Cuzco, se refiere a las danzas ejecutadas en esas ceremonias. De lo poco que, en esta materia, nos ofrece deducimos que fueron danzas ceremoniales en homenaje al Creador. En efecto, la danza Huaylluni del mes de mayo era para "adorar al Creador". En el mes de julio danzaban y cantaban la canción Yahuayra, "suplicándole al Creador un año próspero". En Agosto la danza de turno era la Alancitua para dar gracias al Creador "por habérseles aparecido en ese día".

En el estudio de las danzas contemporáneas del Sur del Perú tampoco hemos encontrado elemento totémico alguno. En su mayoría son danzas ceremoniales, al igual que las del Cuzco, dedicadas al Rayo,-al Trueno. Cuando en alguna de ellas aparece el animal, entonces desempeña un papel secundario, convirtiéndose en danza mimética o mágica, sin relación alguna con el grupo social que la ejecuta.

\section{Nombres.}

Se ha insistido en los nombres que los indios daban a las personas y cosas como reminiscentes de voces relacionadas con animales. Sobre esta base afirman la existencia del totemismo en el Perú.

Esta hipótesis carece de fundamento porque el estudio de los idiomas y dialectos existentes en tiempos de la conquista fué deficiente, aun en el caso del quechua y del aimara. Los cronistas cometieron in- 
numerables errores al interpretar el lenguaje indígena. Igual deficiencia se observa cuando los escritores contemporáneos pretenden traducir vocablos aborígenes. Para probar el origen totémico de esas palabras sería necesario estudiar el vocablo en relación con el grupo social bautizado con el nombre en cuestión.

Los cronistas nos ofrecen dos hechos en relación con los nombres. Cieza de León dice que las palabras usadas se referían a "pueblos, pájaros, hierbas o peces". En cambio, Villagómez asevera que los indios deducían sus nombres de la Huaca.

Suponiendo que tales nombres tuvieran origen totémico, encontraríamos vestigios de ello en el grupo social, llamado Ayllu. Hemos realizado una cuidadosa investigación sobre la materia y no hemos encontrado correlación alguna entre el nombre del Ayllu y el de sus integrantes. El Ayllu debe su nombre: 1) a un fenómeno de la Naturaleza; a cierta montaña, colina o río- 2) a una ocupación predominante de los miembros del Ayllu.-3) a la existencia de cierta cantidad de animales o plantas en el lugar en donde el Ayllu se ha establecido.

Hay quienes aseveran que "el Ayllu mantiene su designación totémica y que los apellidos indios preceden, en gran número de esa fuente". En el Cuzco había 83 ayllus, de los cuales seis llevan el nombre de animales. Alcedo, en su Diccionario, ofrece el nombre de 79 provincias del Perú; de éstas sólo cinco han sido traducidos como nombres de animales. En la región del Collao, en el distrito de Santa Rosa, hay 5 ayllus, ninguno impone su nombre a los miembros integrantes. Así, en el Ayllu Chinchillapa, los miembros del ayllu se apellidan Cham-
billa.

Por lo tanto si los ayllus historicos y gran parte de los ayllus, aun existentes en distintas regiones del Perú, no tienen nombre de animales ilus nombres de sus miembros no guardan relación con el de los Aydada en los rechazar la opinión de la existencia del Totemismo, fundada en los nombres.

Resumen.

la vida relificado el estudio del papel desempeñado por los animales en clusiones: 1.- Tienen escaso valor los datos proporcionados por los cronistas
en relación con los animales considerados como Tótemes.

2.- La adoración de animales atribuída a los peruanos sólo es, en realidad, la veneración indirecta a los dioses estelares.

3.- No puede sostenerse la adoración de los animales porque en le hubiera implicado peruana no hay huella de culto zoolátrico que

4.- Los sacrificios ejecutados con animales son acciones
destinadas a conseguir el bienestar de la colectividad. 
5.- Los animales que no recibían especial homenaje eran en aigunos casos protectores, y en otros propiciadores.

6.- Los animales no aparecen como ancestrales porque en los Ayllus primitivos y en los actuales no se encuentran vestigios de alguna relación de parentesco.

7.- Los animales aparecen subordinados a entidades celestes.

8. - No hay vestigios de Tabú en relación con los animales considerados sagrados o totémicos.

9.- Las danzas se verificaban en honor de las deidades celestes, con tendencias miméticas y mágicas, orientadas hacia la obtención
de alimentos.

10.- Los nombres designan fenómenos de la naturaleza. En algunos casos los ayllus llevan nombres de animales pero no hay relación entre el nombre del ayllu y el de los miembros del mismo.

Por estas razones afirmamos que el totemismo animal no existió entre los antiguos peruanos. Estas conclusiones resultan con mayor evidencia en el estudio que hemos verificado acerca de la llama, el puma, el cóndor y el pez, considerados como animales totémicos.

\section{LA HUACA}

La Huaca fué un elemento religioso y social entre los antiguos peruanos. Ha sido objeto de varias definiciones e interpretaciones.

Garcilaso sugiere gue la palabra Huaca es "Nombre que no permite que de él se deduzca verbo, para decir idolatrar". Considera como Huaca toda cosa sagrada: los ídolos, las peñas, las piedras grandes, los árboles. Las cosas ofrecidas al Sol como figuras de hombres, aves hechas de oro, plata o palo. Los templos grandes y chicos, los sepulcros, las cosas hermosas y aquellas que salen de su curso natural. Son también Huacas, las fuentes caudalosas, los ríos, la cordillera de la Sierra nevada, los cerros muy altos y las grandes cuestas que se hallan por los caminos. Estas Huacas, según Garcilaso no eran tenidas por diocomunes: por esta causa la miraban y tratabantaja que hacían a las peto".

Para Arriaga, la Huaca comunal es de "ordinario de piedra y las más veces sin figura ninguna, otras tienen diversas figuras de hombres - mujeres, y algunas de estas Huacas dicen que son hijos o mujeres ticulares nombres con que les invocan y nales. Todas tienen sus parbiendo hablar no sepa la Huaca de su Ayllu hay muchacho que en sadad de ayllu tiene su Huaca principal y otra por que en cada parcialiellas suelen tomar el nombre de aquel Ayllu". 
Este concepto de Huaca ha sido interpretado de diferente manera por los sociólogos y etnógrafos.

Para Markham la Huaca es un dios ancestral y más tarde un emblema. Distingue la Huaca del dios guardián, llamado Conopa y establece la relación entre la Huaca y los miembros del Ayllu. Confunde la Huaca con la Pacarina y el Mallqui a los que atribuye indistintamente el mismo valor de antepasado y de emblema.

Lang, comete el mismo error y sugiere que las Huacas fueron imágenes de los animales sagrados admitidos en el templo del Sol.

Cunow distingue en el Perú tres cultos: 1) Pachacamac. 2) Huaca. 3) Conopa. Filológicamente la palabra Huaca, según Cunow tiene la partícula Hua, antiguo vocablo peruano que significa Yo. Por tanto, la "Huaca de un indio, estaba relacionada con su ego por la procreación o vínculo sanguíneo porque los indios la consideraban como su antecesor".

Payne, considera la importancia económica de la piedra y explica por qué la piedra fué el material de la Huaca. Filológicamente, para Payne, Huaca es simplemente el verbo Huacan. Sugiere que la Huaca as el oráculo del Ayllu y el vigilante del pueblo.

Joyce opina que la Huaca fué adorada como ancestral. Son de la isma opinión Muller y Bastian.

Otros escritores, entre ellos, Hagar, Spencer, Tschudi y Karsten consideran a la Huaca como objeto sagrado, como fetiches, o como sitio de residencia de las almas.

\section{Diferencia entre Huaca, Conopa, Pacarina y Mallqui.}

Los mencionados escritores emplean indiferentemente las palabras enunciadas en "esteg parágrafo. Esta Confuisión motiva la interpretación de la Huaca. Después de un análisis exhaustivo, he llegado a las siguientes conclusiones: 1.- La Huaca es el ancestral, tenía pareiacionados e hijos. Podían procrear por sí solas, $y$, por eso, estaban reniesco. Z. 3. - La Conopa, La Pacarina es el lugar geográfico de origen del Ayllu. pasado inmediato la deidad de la familia. 4.- El Mallqui era el anteSacerdocio.

Hubo sacerdocio y ceremonias especiales dedicadas a la Huaca. El sacerdote de cada Huaca era independiente y cada uno tenía su y el designado para el Sia entre el sacerdocio dedicado a la Huaca mientras que el del Sol Sol. El sacerdocio de la Huaca era hereditario Sacrificios.

La diferencia entre las dos clases de sacerdocio se ve con más claridad cuando se estudia los sacrificios y las ceremonias ejecutadas 
en homenaje de la Huaca y el Sol. Cuando se sacrificaba en honor al Sol, Ia ceremonia era la naturaleza mágica. En el caso del sacrificio para Ia Huaca era de orden social.

Festividades.

En el período del Incanato, las festividades enumeradas por los cronistas guardan estrecha relación con las Huacas. En esas fiestas es. taban representados, con sus respectivas Huacas, los Ayllus pertenecientes a los primitivos Ayllus ancestrales que siguieron a los Ayars; los de descendencia real; los Ayllus de alto rango y los Ayllus comunes. La ceremonia del banquete, la asamblea de la Nobleza, la gente que venía de todas partes, la distribución del pan sagrado, todos esios hechos sugieren una ceremonia comunal. Se puede suponer que aquella comunión tuvo relación con el primitivo clan totémico, pero el cnálisis de Ia organización del Ayllu muestra que dicha-ceremonia es tribal sin conexión con cualquiera clase de totem.

Nombres.

El nombre que se daba a los niños ha dado motivo a especulaciones de todo orden, en especial cuando se ha tratado de encontrar fuentes totémicas.

Villagómez dice: "Todos los indios tienen el nombre de sus Huacas. Cada vez que ellos se nombran u otros los llaman, siempre dicen primero el nombre del indio, que el nombre cristiano del bautizo. Cuando les ponen nombre ayunan y festejan a la Huaca". El mismo Villagómez cuando instruye a los visitadores les dice: "Ningún indio ni india se llamará con nombrie de la Huaca hi del irayo"so"

Es evidente que los indios, en gran parte se distinguían por el nombre de su Huaca, pero estos nombres eran de cuerpos celestiales, fenómenos de la naturaleza, animales, lugares en donde abundaban ciertos animales, plamtas o minerales. En todo caso nunca, los animales, fueron considerados como Huacas.

Fetiches.

Se ha considerado a la Huaca como fetiche. Hemos ofrecido bastantes hechos para probar que la Huaca estuvo relacionada con el Ayllu por lazos sociales y místicos. En este sentido la Huaca se refiere a un grupo social al cual le dió su nombre y recibió homenaje democrático. Tales circunstancias nunca aparecen en el fetiche. El fetiche jamás es considerado como miembro del grupo social, ni da su nombre a la comunidad, ni es considerado como ancestral. Las ceremonias en honor de un fetíche tienen contenido mágico; en cambio las ofrecidas a la Huaca tuvieron carácter social, en la cual la remembranza histórica, la comunión entre los miembros del Ayllu, la protección dada a elios, fueron más importantes que cualquiera representación mágica. 
Residencia de espiritu.

No admitimos que la Huaca y la Pacarina fueran residencias de almas, morada de divinidades o lugares habitados por espíritus. Estas interpretaciones no pueden explicar la presencia de la Huaca en cada Ayllu; la idea de descender de la Huaca y por tanto de haber establecido cierto parentesco con la Huaca. Las llamadas habitaciones de espíritus, morada de divinidades no regulan ninguna organización social, como ocurre con la Huaca y el Ayllu. "Los indios, dice el jesuíta anónimo, no creían que había nada divino o sublime ni en las Huacas, ni en los cadáveres".

\section{La Huaca como deidad del Ayllu.}

No admitimos que la Huaca fuera deidad del Ayllu. Cada Ayllu tuvo su propia divinidad, completamente diferente en naturaleza a la Huaca, Pacarina, Conopa o Mallqui. Las divinidades de Ios Âylìs ueron generalmente cuerpos celestiales o fuerzas de la naturaleza. Ninguna de esas deidades eran consideradas como ancestrales de la comunidad y por tanto permanecieron al margen del parentesco del grupo social.

La Huaca como oráculo.

Es cierto que algunas Huacas sirvieron de oráculo, pero ellas fueron específicamente determinadas para tal propósito. Eran Huacas menores con sacerdocio especial como hechiceros y agoreros, independientes de aquellas que determinaban el parentesco en el Ayllu.

Lá Huaca y el culta al ancestral.

Los antiguos peruanos tuvieron realmente dos ancestrales:

1.- El Mallqui, el ancestral inmediato, mejor dicho el antepasado, o sea el cadáver del padre, abuelo o bisabuelo; en algunos casos con sus esposas y parientes.

Eran ancestrales de las familias relacionadas con ellos por consanguinidad. En consecuencia había muchos Mallquis.

2. - La Huaca, el ancestral mediato, la colina, la piedra, la roca etc. Fué el ancestral del Ayllu relacionado con sus miembros por medio de parentesco social. Era elemento único.

De acuerdo con Arriaga, la Huaca y el Mallqui eran adorados bajo el principio de do ut des. Pero según el Jesuíta anónimo "los peruanos no rendían culto al muerto, ni aun cuando los cadáveres fueran de los reyes, menos a los sepulcros llamados Huacas". 
Los indios tuvieron una actitud mental distinta hacia cada uno de esos elementos. El homenaje a la Huaca era una expresión colectiva desde que la Huaca significaba la tradición del Ayllu y representaba al ancestral de todas las familias del grupo social.

El homenaje al Mallqui fué la expresión específica de los miembros de la familia hacia los cadáveres de sus parientes consanguíneos.

Si queremos traducir tales hechos en términos de culto al ancestral, podemos concluir diciendo que los Mallquis y no la Huaca eran objeto de semejante culto. Esto es evidente desde que los Mallquis tenían relación inmediata con la familia cuyos miembros podían verlos y ofrecerles sacrificios. Con la Huaca la relación fué más distante y a través de los Mallqui. Por tanto el culto a la Huaca estaba más cerca de la divinidad que del ancestral. Este punto de vista aclara la posición de Markhan, Cunow y Joyce. El culto al ancestral, es el "Culto a la momia", según Lang; y aquel ancestral, el Mallqui fué el "primer ancestral humano creado por la Huaca", de acuerdo con Cunow; y no la deidad y ancestral como sugiere Markham. Por lo tanto, "El culto de la Huaca estuvo unido con la adoración al ancestral", de acuerdo con Joyce, en este caso los Mallqui.

Resumen.

1.-- La Huaca es el elemento esencial del Ayllu con cuyos miembros establece relación de parentesco. 2.- La Huaca no es emblema, ni fetiche, ni habitación de espíritu, ni
es objeto de culto al ancestral.

3.- La Huaca establece, además, relación mística, con el Ayllu y los miembros que lo integran. Esa relación tuvo carácter democrático imposible de confundirlo con el culto a las deidades o ancestrales, donde son necesarias la jerarquía y la subordinación.

4.- Su naturaleza totémica será consecuencia del estudio del Ayllu.

\section{EL AYLLU}

La organización social de los antiguos peruanos, llamada Ayllu, ha dado motivo a varias importantes investigaciones desde el punto de vista económico. Incidentalmente, los sociólogos y etnólogos, se han referido al Ayllu, considerándolo haber pasado por un período totémico; pero, hasta hoy, no se ha hecho una investigación profunda para afir-
mar que el Ayllu fué un grupo social totémico.

Después de haber estudiadó el origen y desarrollo del Ayllu, podemos resumir sus elementos de la siguiente manera:

1.- Un grupo social en el cual se unieron varias familias. 
2.- Cierto parentesco entre los miembros del grupo social.

3.- La creencia que los miembros del Ayllu descendían de las Huacas.

4.- La posesión de cierto territorio y de cierta cantidad de ganado.

5.- Un sistema de gobierno en donde la comunidad fué predominante.

Significado de la palabra Ayllu.

En quechua de acuerdo con Holguín, Ayllu significa pariente, pero no parentesco consanguíneo para lo cual hay vocablos especiales. En aymara Bertonio ha traducido la palabra Ayllu como parcialidad, palabra castellana introducida para explicar el sistema de agrupación decimal atribuído a los incas. El mismo Bertonio nos ofrece la palabra hatha como expresión de "Casta-familia". Este vocablo sobrevive en algunos Ayllus del Collao. Así se denomina al grupo más joven del Ayllu con el término Hila - hatha - ura, y al más viejo con el de Sullca hatha - ura. Los jefes de los Ayllus del Collao se llaman Hilacatas, una corrupción de Hila - hata. Es obvio que la palabra hatha expresa, en legítimo aymara, la idea de parentesco, como la del Ayllu.

Trimborn anota que cualquiera que sea la traducción dada a la palabra hatha conocida después por Ayllu, no podfía ser identificada con la familia española, y por eso hubo necesidad de agregar la palabra Casta que significa Clan. Trimborn sostiene que ambas definiciones casta y familia tienen para Bertonio el concepto de comunidad unida por parentesco.

En consecuencid tanto en el idioma quechua como en el aymara hubo palabras para, expresar lacided lde parentesco.

Parentesco en el Ayllu.

Hemos estudiado el vocabulario correspondiente al parentesco en los idiomas dominantes quechua y aymara, llegando a la conclusión de haber existido, en el Ayllu, el sistema clasificatorio de parentesco.

De ese estudio resulta lo siguiente; en quechua y aimara:

1.- Que existen nombres para denominar a los parientes de la línea ascendente y descendente.

2.- Los sobrinos y las sobrinas están clasificados con los hijos e hijas.

3.- Que existen vocablos usados entre hermanos y hermanas.

4.- Que entre los quechuas no hay términos especiales para distinguir a los parientes según la edad.

5.- Que tanto en quechua como en aymara, las palabras usadas para nombrar a los primos son las mismas que se emplean para 
referirse a hermanos y hermanas. Ocurre lo mismo para los primos en segundo y tercer grado.

6. Existen vocablos para designar parientes políticos.

7.- Que en aymara esta clase de parentesco aparece clasificada con el nombre del padre, de la madre o del hijo.

8. Finalmente existen términos para denominar a parientes de dos y tres generaciones mayores de quien habla.

$\mathrm{De}$ acuerdo con las reglas dadas por Rivers acerca del parentesco clasificatorio, encontramos en el Perú los siguientes elementos:

a) - Hay vocablos generales aplicados a un gran grupo de personas. Todos los hermanos y sus esposas; y todas las hermanas y sus esposos, así como los pirmos de ambos sexos y sus esposas, llaman padre, madre, tío y tía de la misma manera que los hijos y sobrinos y sus esposas.

b) - Los hermanos y hermanas se distinguen entre sí; en quechua de acuerdo con el sexo del que habla y, en ambos idiomas, de acuerdo con la edad.

c) - La distinción entre parientes por la línea materna y paterna es evidente como aparece en los vocablos aplicados a los tíos y tías, sobrinos y sobrinas. d)- La distinción entre los hijos de hermano del padre y los del her-
mano de la madreces obvia.heli Converso"

e)- Hay en ambos idiomas los mismos términos para nombrar al padre y al hermano del padre; a la madre y a su hermana. Pero los términos para la hermana del padre y el hermano de la madre son diferentes.

De todas las referencias relativas con el parentesco podemos conciuir que el sistema clasificatorio entre los peruanos estuvo relacionado con ciertos derechos, privilegios y restricciones cumplidos por los miembros del grupo social. Entre estos hechos, el más importante es la superioridad del tío materno, considerado por muchos escritores como prueba del predominio del derecho materno entre los peruanos y consecuentemente la existencia del totemismo.

Organización dual.

El sistema clasificatorio del parentesco está relacionado, en los pueblos totémicos, con una organización dual de la sociedad, de la cual hay pruebas evidentes de haber existido entre los antiguos peruanos. 
Cuando llegaron los españoles al Perú encontraron la ciudad del Cuzco dividida en dos secciones: Hanan-Cuzco y Hurin-Cuzco. Tal división no era una simple distribución geográfica, tenía un concepto más amplio, en el cual aparece que los grupos sociales tenían su propia historia, poseían cierto territorio, estrictamente limitado, perteneciente a grupos de familia unidas por lazo de parentesco. En el Cuzco, este hecho resulta exacto porque tanto los Hanán y Hurin Cuzco reclamaban, para sí, el derecho de Incanato fundándose en el linaje. Cuando tal división significa linaje entonces se expresaba ese hecho con los vocablos Hanan - Ayllu y Hurin - Ayllu o sea el linaje alto y el bajo. Los Collas, expresaban la misma idea con las palabras: Hila, mayor y Sullca, menor, agregándole la palabra Hatha que significa linaje.

Cuando esta idea, de linaje, está asociada con el territorio, entonces se habla de Hanan-suyu y Hurin-suyu. En otros casos en los cuales el quechua no fué usado para expresar la idea de división, como ocurre en la región de Huánuco, entonces se emplean las palabras: Allanca e icho, y se dice allanca-pincos, icho-pincos; allanca-huaris, icho - huaris.

El dato más importante sobre esta materia lo ofrece Príncipe cuando se ocupa de algunos Ayllus en la región central de la Sierra. El Ayllu aparece dividido en dos grupos definidos, poseedores, cada uno de su Huaca, Pacarina, Conopa, Mallquis y Huacas menores. Los del grupo alto eran los nativos, los primeros colonizadores a quienes les denominaban Huaris - grandes o gigantes- o Llactayoc. Los del grupo bajo eran los extranjeros, los que habían llegado después a quienes se les llamaba Llacchuasis, parásitos.

Los Llactayoc como nativos y fundadores del Ayllu tenían ciertos privilegios como los de tener más Huacas que los Llacchuases a quienes, en algunos casos no les era permitido ofrecer , sacrificios a la Huaca de la comunidad. Los Huaris, además de su Huaca tuvieron una Pacarina local y los Mallquis o momias de los muertos más recientes. Los Llacchuasis no tenían más ancestrales que los Mallquis. Sin embargo este hecho no fué general. Así, en los Ayllus de Recuay, los Llacchuases iuvieron Huacas y Pacarinas. Además adoraban al rayo, en el cual estaban representadas tres personas: Lliviac, el rayo; Namoc, el Padre; y Uchu Lliviac el Hijo de quienes los Llachuases creían descender. El parentesco y la Huaca.

Es evidente que los indios trazaron su genealogía de las Huacas. En el caso de Ocros, los cuatro Ayllus que integran esa región tienen un ancestral común: La Huaca, llamada Carhua-Huanca la cual tiene cuatro hijos: Parana, Caja-Yanac, Chirao-Icochay Ninas-Pocos.

El primero no tiene descendientes; el segundo lo tuvo, uno de ellos aparece con dos hijos, de los cuales el primero tiene siete hijos y una hija. El tercer hijo de la Huaca principal aparece con gran número de descendientes. De uno de ellos empieza una nueva rama. Finalmente el cuarto hijo tuvo tres; dos dejaron descendientes.

Los miembros del Ayllu se distinguían por el ancestral común, la Huaca, pero en sus nombres no hay relación con el nombre del ances- 
tral. Aun en tiempos del régimen español cuando los descendientes de la Huaca tenían nombres cristianos, el nombre de la Huaca no aparece como distintivo del Ayllu. Por ejemplo los dos hijos de Santiago Lloaclla Lliuyac, de la rama de Huayna Poma perteneciente a la Huaca Chirao Icocha tienen apellidos diferentes: se llaman Pablo Surca y Pedro Montalao. Por tanto el nombre de la Huaca es distintivo del Ayllu pero no de los individuos.

\section{Matrimonio.}

Las numerosas referencias, acerca del matrimonio, ofrecidas por los cronistas dificultan juzgar, esa institución, basándose en una teoría específica. Hubo promiscuidad, matrimonio por grupo, poligamía, poliandría, matrimonio patrilocal, endogamia y exogamia.

La existencia del totemismo entre los antiguos peruanos ha sido sugerida como consecuencia de la exogamia. Esta hipótesis no tiene fundamento porque la exogamia no es un elemento primario del totemismo, ni el totemismo podría ser explicado bor exogamia. Hay grupos exogámicos sin totem, aunque no hay clanes totémicos sin exogamia. Como no hary un solo Ayllu en el Perú relacionado con algún totem, la exogamia peruana tiene otra explicación. La orranización dual en el Perú fué consecuencia del sistema de agrupación. Los colonizadores estaban divididos en antiguos y recientes habitantes de determinada región. La denominación atribuída a esos grupos no tiene la más leve referencia a un animal. En la organización totémica coda mitad de un clan tiene su totem $y$, en consecuencia, no es permitido el matrimonio entre los miembros que tienen el mismo totem. Tales circunstancias no aparecen en la exogamia de los peruanos. La división del Ayllu no tuvo propósito místico; su esencia fué de naturaleza económica en la que el li-

Los cronistas ofrecen pocos datos acerca de la exogamia; en cambio hay referencias precisas sobre la existencia de la endogamia. Garcilaso dice que los nativos de una provincia no podían casarse con los de otra, ni los de un pueblo en otro sino "todos en sus pueblos y dentro de su parentela por no confundir los linajes y naciones, mezclándose unos con otros". Esta endogamia puede considerarse como institución reciente cuando el Ayllu estuvo definitivamente constituído.

\section{Resumen.}

1.- El Ayllu es un clan con una organización social en la cual, sus miembros, están unidos por lazos de parentesco.

2.- El Ayllu está relacionado con un elemento, llamado Huaca que en-
vuelve la idea de descendencia. 3.- La Huaca no es totem del Ayllu, porque en'la división dual no apa-
rece predominio alguno del totem.

4.- La exogamia y la endogamia no guardan relación con la Huaca: fueron factores sociales y económicos del Ayllu. 
$-172-$

5.- La Huaca fué el elemento místico que satisfizo la ansiedad mental de los miembros del Ayllu para encontrar una explicación sobre su lejano ancestral.

CONCLUSIONES

1.- No hay huellas de totemismo en el Perú. Los animales considerados como tótemes son elementos simbólicos y mágicos.

2.- No hay huellas de totem en el Ayllu.

3.- Que la llamada Huaca es el elemento místico del Ayllu, y no totern.

Biblioteca de Letras

"Jorge Puccinelli Converso" 